\title{
Krytyka millenarystycznego obrazu Jerozolimy u św. Hieronima ze Strydonu
}

Fenomen millenaryzmu dał o sobie znać u początków chrześcijaństwa. Ta doktryna sięgała swoimi korzeniami judaistycznej koncepcji nadejścia królestwa mesjasza na ziemi. Osią przekonań chiliastów była wiara, że przed końcem świata i zanim dokona się sąd ostateczny, nastąpi pierwsze zmartwychwstanie tylko sprawiedliwych, którzy w Jerozolimie niebiańskiej umiejscowionej na ziemi przez tysiąc lat (millennium) mieliby cieszyć się wraz z Chrystusem szczęściem i obfitością wszelkiego dobra $^{2}$.

Do tych wizji, w sposób krytyczny, nawiązywał Hieronim ze Strydonu. W jego przekonaniu pojawiły się poważne powody, by występować przeciwko zniewolonym dosłownością tekstu i ,judaizującym”, do których zaliczano millenarystów.

1 Dr hab. Mieczysław Celestyn Paczkowski OFM, prof. UMK, Katedra Teologii Historycznej na Wydziale Teologicznym Uniwersytetu Mikołaja Kopernika w Toruniu; e-mail: celestyn@umk.pl; ORCID: 0000-0002-4045-2314.

2 Por. M. Simonetti, Millenarismo, w: NDPAC, t. 2, ed. A. Di Berardino, Genova 2008, s. 3280; P. Paciorek, Czas kresu czasów w literaturze apokaliptycznej, VoxP 62 (2014) s. 418-420. Temat millenium łączył się z przekonaniem o ograniczonym czasie istnienia świata wyznaczonym na siedem tysięcy lat. 


\section{Antymillenaryzm Hieronima}

Mimo że Hieronim przyjmował i propagował tradycje judeochrześcijańskie, był jednak czujny, jeśli chodzi o redukowanie znaczenia Pisma Świętego w jego sensie pełnym i duchowym. Nawiązania do idei materialistycznych judaizujących chrześcijan stanowiły często pretekst, aby przedstawić interpretację duchową ${ }^{3}$. Prymitywna dosłowność była dla niego nie do przyjęcia, chociaż już u autorów starochrześcijańskich autor Wulgaty uchodził za znawcę Starego Testamentu i eksperta w zakresie judaistycznych metod egzegezy biblijnej .

To właśnie judaizujących dotyczy zbiór licznych tekstów opisujących wizje eschatologiczne i wypełnienie się czasu. Przedstawiciele tych kręgów należeli do hołdujących „literze, która zabija"5.

Antymillenarystyczne nastawienie św. Hieronima stanowi niezaprzeczalny fakt ${ }^{6}$. W swoich rozważaniach i polemikach przywołuje on elementy millenaryzmu w około pięćdziesięciu tekstach swoich dzieł? Strydończyk był zresztą zaskoczony, że millenaryzm propagowali niektórzy szczerzy wyznawcy Chrystusa ${ }^{8}$, jak również ,wielu spośród starożytnych”9 oraz „wiele osobistości Kościoła i męczennicy”"10. Autor Wulgaty

3 Na temat egzegezy antymillenarystycznej Strydończyka, por. J.-N. Guinot, Théodoret et le millénarisme d'Apollinaire, ASE 15/1 (1998) s. 173-178.

4 Dla Strydończyka prawda Pisma Świętego zamieszkiwała nie w samym porządku słów, ale w ich sensie. Zalecał, by zwracać się do oryginału hebrajskiego, aby „odszukać w strumykach to, co płynie ze źródła” (Epistula 106, 2). W liście skierowanym do Pammachiusza Hieronim wskazywał na to, że veritas hebraica miała przywilej przekazywania boskiego objawienia, gdyż w Piśmie Świętym „nawet kolejność słów jest tajemnicą". Hieronymus Stridonensis, Epistula 57, 5, 1.

5 Por. Hieronymus Stridonensis, Commentarii in Esaiam LX 1-3; XLIX 14-18; XLVIII 12; LXVI 20.

6 Por. Simonetti, Millenarismo, s. 3282.

7 Zob. J.P. O'Connell, The eschatalogy of Saint Jerome, Mundelein 1948, s. 64-65.

8 Hieronymus Stridonensis, Commentarii in Ezechielem XI 36; Hieronymus Stridonensis, Commentarii in Esaiam V 19, 23.

9 Hieronymus Stridonensis, Commentarii in Esaiam XVIII (prol.).

10 Hieronymus Stridonensis, In Hieremiam prophetam IV 15. 
nie przemilcza więc faktu, że millenaryści stanowili znaczącą grupę nie tylko wśród heretyków, ale także autorów prawowiernych. Egzegeta łaciński zaznacza, że wiara w tysiącletnie królestwo i odnowę ziemskiej Jerozolimy jest związana z Żydami i ,judaizującymi chrześcijanami”"11 lub ebonitami będącymi spadkobiercami tych idei ${ }^{12}$. Prymitywny millenaryzm przypisuje głównie charakterystycznej „triadzie” (Iudei, semiiudei et iudainzantes nostri) przywoływanej w kontekstach egzegetycznych i doktrynalnych ${ }^{13}$. W czasach Strydończyka były to już wąskie grupy sekciarskie wegetujące na obrzeżach Kościoła powszechnego. Należy to podkreślić, gdyż chiliazm był opisywany nie tylko w kontekście przeszłości, ale także jako aktualny problem Kościoła.

Wymieniani przez Strydończyka ,judaizujący” raczej mogli mieć niewiele wspólnego (a może nawet nic) z judaizmem rabinackim ${ }^{14}$. Millenaryzm odizolowanych, pojedynczych grup wiernych miał więc przede wszystkim zabarwienie mesjanistyczne. Podkreślano, że chodzi o królowanie Chrystusa i „Jego świętych”. Oczekują oni tego, co wierzący w Chrystusa już otrzymali, są więc po prostu fałszywymi chrześcijanami. Ponadto ,[mają] duszę żydowską, mimo, że nie są obrzezani na ciele"15. Należących do tej grupy należy nazwać „synagogą”, a nie Kościołem ${ }^{16}$.

11 Por. Hieronymus Stridonensis, Commentarii in Esaiam V 23, 18; XV 54, 1; Hieronymus Stridonensis, In Hieremiam prophetam II 110; Hieronymus Stridonensis, Commentarii in Ezechielem XI 36, 37, 38; Hieronymus Stridonensis, Commentarius in Osee I 2; Hieronymus Stridonensis, Commentarius in Ioelem III 7, 17; Hieronymus Stridonensis, Commentarius in Zachariam III 14, 18, 19. Zob. R.L. Wilken, Early Christian Chiliasm, Jewish Messianism, and the Idea of the Holy Land, HTR 79/1 (1986) s. 298-307.

12 Hieronymus Stridonensis, Commentarii in Esaiam XVIII 66, 20; Hieronymus Stridonensis, Commentarii in Ezechielem XI 39; Hieronymus Stridonensis, Commentarius in Michaeam I 4, 1-7.

13 Na temat różnych określeń millenarystów, por. O’Connell, The eschatalogy, s. 66 z przypisami.

14 Por. H.I. Newman, Jerome’s Judaizers, JECS 9/4 (2001) s. 421-422, przyp. 2.

15 Hieronymus Stridonensis, Commentarius in Sophoniam III 14-18.

16 Por. Hieronymus Stridonensis, Commentarius in Sophoniam III 19-20. 
Strydończyk w swoim komentarzu do Księgi Izajasza mówił o chiliastycznej egzegezie „Żydów, ebionitów, spadkobierców błędu żydowskiego [...]. [To ci], którzy oczekują rozkoszy tysiącletniego królestwa"17. Hieronim opisywał millenarystów jako semiiudaei ${ }^{18}$, używając tego określenia w innych miejscach, aby wskazać na Ebiona i ebionitów ${ }^{19}$. Jednoznacznie wskazał przy tym, że ich doktryna przyjęła heterodoksyjny charakter. Ebionici ściśle przestrzegali Prawa Mojżeszowego ${ }^{20}$, a Chrystus był dla nich jedynie człowiekiem obdarzonym szczególną mocą ${ }^{21}$. Przedstawiciele tej grupy czcili Jerozolimę jako „dom Boży”22 i tego przywiązania do świętego miasta nie porzucili. Daje się zauważyć u nich przedłużenie mesjanizmu judaistycznego o charakterze materialnym, uzależnionym od dosłownej interpretacji proroctw ${ }^{23}$.

Strydończyk dosyć swobodnie posługuje się określeniem mającym na celu zdyskredytowanie ebionizmu ${ }^{24}$, a jego polemika sugeruje szerokie odniesienia do millenaryzmu tej sekty. Tak jednak nie jest. Mamy w zasadzie tylko jedno konkretne świadectwo o millenarystycznych przekonaniach ebonitów. Chodzi o komentarz do Księgi Izajasza ${ }^{25}$. Nie jest

17 Hieronymus Stridonensis, Commentarii in Esaiam XVIII 66, 20.

18 Por. Hieronymus Stridonensis, Commentarii in Esaiam XV 54, 11-14; 60, 1-3, 10-12; Hieronymus Stridonensis, Commentarius in Sophoniam III 14-18.

19 Por. Hieronymus Stridonensis, Commentarii in Epistulam Pauli Apostoli ad Galatas III 14; Hieronymus Stridonensis, Commentarii in Esaiam II 22. Uważa się, że ruch ten nie został założony przez samego Ebiona, ale miał innych fundatorów. Postać, od której sekta przyjęła nazwę, to jedynie najważniejszy jej przedstawiciel i ideolog.

20 Por. G.G. Stroumsa, Savoir et salut, Paris 1992, s. 114, przyp. 17; J. Lieu, History and Theology in Christian Views of Judaism, w: The Jews Among Pagans and Christians, ed. J. Lieu - J. North - T. Rajak, London 1994, s. 89-90.

21 Orygenes, opierając się na grze słów (Ebion - 'ubogi'), ukazuje „ubóstwo” ebionitów w zakresie interpretacji duchowej (chrześcijańskiej) Pisma Świętego.

22 Por. Irenaeus Lugdunensis, Adversus haereses I 26, 2.

23 Por. J. Daniélou, Théologie du Judéo-Christianisme, Histoire des doctrines chrétiennes avant Nicée 1, Paris - New York - Rome 1958, s. 343.

24 Por. J.E. Taylor, Christians and the Holy Places. The Myth of Jewish Christian Origins, Oxford 1993, s. 22.

25 Por. A.F.J. Klijn - G.J. Reinink, Patristic Evidence for Jewish-Christian Sects, Leiden 1973, s. 72. 
to powód, aby a priori takową identyfikację odrzucać, lecz wskazana jest ostrożność.

Członkowie sekty ebionitów tworzyli wraz z innymi judaizującymi swoisty amalgamat. Stąd pytanie o tożsamość pozostałych zwolenników chiliazmu w egzegezie i przepowiadaniu. W drugiej strony Hieronim wskazuje na konkretne postaci reprezentantów millenaryzmu nienależących bynajmniej do mniejszościowej grupy błędnowierców. Najwyraźniej chiliazm o znamionach judeochrześcijańskich stanowił dla nich atrakcyjną alternatywę.

Nic więc dziwnego, że również inne grupy judeochrześcijan ${ }^{26}$ odczytywały w podobny sposób proroctwa Księgi Izajasza ${ }^{27}$ i Księgi Ezechiela $^{28}$. Dochodziły do tego perykopy proroków mniejszych, jak Księga Joela i Księga Ozeasza ${ }^{29}$. Teksty te odnosiły się do odnowionej Jerozolimy w jej konkretnym kształcie ${ }^{30}$. Grupy judeochrześcijan były przekonane, że obietnice odbudowy Jerozolimy nie ziściły się z chwilą przyjścia Chrystusa. Miałoby to nastąpić przy powtórnym Jego przyjściu. Teksty prorockie sugerowały, że stanie się On budowniczym chwalebnej stolicy. Ebionici pod tym względem byli frakcją radykalną, chociaż wyrażali uczucie obecne wśród innych grup judeochrześcijan. Ich argumenty stanowiły nie tylko proroctwa, ale także księga Apokalipsy Janowej (por. 21,1-22,5)

Niektóre wzmianki dotyczące millenaryzmu pojawiają się $\mathrm{w}$ dziełach Hieronima napisanych pomiędzy 393 a 398 rokiem. Jednak więk-

26 Należy tu wymienić grupę tzw. nazarejczyków.

27 Por. Iz 11,6-9; 44,28; 45,13; 49,17; 54,11; 60,10; 65,17-25; 66,20.

28 Por. Ez 37,20-28 oraz całą końcową część księgi 40,1-48,35.

29 Zob. Hieronymus Stridonensis, Commentarius in Hoseam II 14-15, 21-24; Hieronymus Stridonensis, Commentarius in Joelem III 7-8, 16-17.

30 Krytyką tych błędów zajmuje się Hieronim w Commentarii in Esaiam. Por. S. Gozzo, De s. Hieronymi Commentario in Isaiae librum, „Antonianum” 35 (1960) s. 203-205.

31 Euzebiusz z Cezarei łączył millenaryzm z nurtami apokaliptycznymi przedstawianymi w niekorzystnym świetle. Por. Eusebius Caesariensis, Historia Ecclesiastica VII 24, 4, 5. 
szość antychiliastycznych refleksji znajduje się w dziełach powstałych po 406 roku. Sugerować to może, że potępienie orygenistów w 400 roku ośmieliło radykalnych zwolenników millenium do głoszenia swoich tez. To sprowokowało św. Hieronima do ostrzejszej reakcji. Jednak właśnie wtedy powstają komentarze do ksiąg prorockich i jest zrozumiałe sięganie po wątki antimillenarystyczne.

Przełom IV i V wieku to również okres wzmożonych oczekiwań eschatologicznych, o czym świadczą spekulacje na temat dat przyjścia Chrystusa w chwale i zapowiedzi końca świata. Być może Hieronim zareagował na ówczesne zjawiska. W każdym razie nie brakowało powodów, dla których egzegeta łaciński był owładnięty myślą o konieczności zwalczania millenaryzmu. W okresie gdy komentował księgi proroc$\mathrm{kie}^{32}$, sięgał po wcześniejsze komentarze, a w pamięci powracał do nauk z przeszłości, szukał materiału do swoich rozważań i dostrzegał słabe strony egzegezy ściśle literackiej. Te braki były widoczne szczególnie w odniesieniu do eschatologicznych obrazów zapowiedzi prorockich. Autor Wulgaty, jak to miał w zwyczaju, nie szczędził cierpkich uwag zwolennikom egzegezy ,żydowskiej” i nie unikał osobistych ataków.

Zapowiadają Żydzi, czy raczej śnią, że w czasie ostatecznym Bóg ich zgromadzi i przywiedzie do Jerozolimy. Niezadowoleni jednak z tak wielkiego szczęścia, Żydzi zapewniają, że ten sam Bóg wyda w ich ręce synów i córki Rzymian po to, by ich sprzedać nie Persom czy Etiopczykom, którzy są blisko, ale Sabejczykom, najdalszemu ludowi. To dlatego, że Bóg przyrzekł, że pomści zniewagę swego ludu. Te rzeczy obiecują sobie oni i nasi judaizujący, pokładając przy tym nadzieję w tysiącletnim królestwie dla siebie, w granicach Judei i w Jerozolimie ze złota. [Wyobrażają sobie] krew ofiar,

32 Komentarze do ksiąg prorockich (tzw. opus prophetale), które ujrzały światło dzienne pod koniec jego życia, stanowią owoc wieloletnich poszukiwań egzegetycznych Strydończyka. Por. J. Braverman, Jerome's commentary on Daniel. A study of comparative Jewish and Christian interpretations of the Hebrew Bible, The Catholic Biblical Quarterly. Monograph Series 7, Washington 1978, s. 10. 
synów i wnuki, niewyobrażalne rozkosze oraz bramy miasta wyróżniające się różnorodnymi klejnotami [...]. Zarówno ci, którzy zostaną ukarani, jak i ci, którzy zostaną wzięci do chwały, uznają, że Pan zamieszkuje w swoim „oglądaniu” (specula) ${ }^{33}$ Syjonu i na Świętej Górze - Chrystusie, czyli w tej siedzibie, którą sobie przygotował jako godną dla Boga ${ }^{34}[\ldots]$. Jak mówiliśmy [błędnowiercy], odnoszą to wszystko do bajki o tysiącu lat, gdy Chrystus zamieszka na Syjonie i w Jerozolimie ze złota i drogich kamieni, aby zgromadzić święte ludy oraz by ci, którzy na tym świecie byli gnębieni przez narody pogańskie, w taki sam sposób mogli rządzić narodami ${ }^{35}$.

Jeśli wierzyć Hieronimowi, panowanie Chrystusa dla judaizujących nabierało bardzo konkretnego znaczenia: miała dokonać się zemsta i zapowiadana odpłata, a gnębicieli „ludu Bożego” czekała bolesna kara. Zgromadzenie ludów i panowanie Chrystusa urzeczywistniały się w chwalebnej Jerozolimie, odnowionej według opisów Apokalipsy Janowej. Strydończyk stara się pokazać, że jego zamiarem jest tylko zreferowanie przekonań millenarystów. Czytelnicy sami ocenią ich wartość, oddzielając „ziarno” właściwej doktryny od „plew” błędu.

Dla łacińskiego egzegety kluczowe jest to, by nie tracić z oczu podstawowych prawd. Tak jest w przypadku zmartwychwstania. Hieronim przypominat:

33 Odwołanie do popularnej etymologii. Orygenes podkreślał wielokrotnie, że w na-

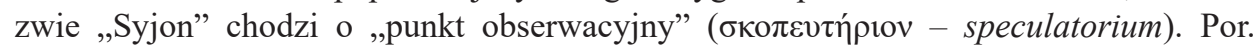
Origenes, In Psalmos 64 (65), 2; 75 (76), 3; 98 (99), 2; 132 (133), 3; Origenes, Homiliae in Isaiam VII 2; Origenes, Homiliae in Jeremiam V 16; Origenes, Commentarii in Johannem XIII 13, 81. Odnośnie do Hieronima, zob. Hieronymus Stridonensis, Tractatus in Ps. 86, 3; Hieronymus Stridonensis, Epistula 108, 9; Hieronymus Stridonensis, Commentarius in Amos I 1.

34 „Syjon znaczy «punkt obserwacyjny». Z tego też powodu w duszy, która posiada znajomość Pisma [Świętego] i jego nauki, zamieszkuje Bóg” (Hieronymus Stridonensis, Tractatus in Ps. 75, 3). Etymologia nazw biblijnych prowadziła starożytnych egzegetów ku głębszemu znaczeniu. Liczne przykłady znajdują się np. w pismach Orygenesa.

35 Hieronymus Stridonensis, Commentarius in Joelem III 1. 
Jest oczywiste, że my nie zaprzeczamy zmartwychwstaniu, lecz twierdzimy, że te wszystkie rzeczy nie zostały napisane odnośnie do zmartwychwstania ciał, lecz aby za pomocą przypowieści odnoszącej się do zmartwychwstania, obwieścić proroctwo o odrodzeniu Izraela [...]. [Pan] mówi bowiem, że zgromadzi synów Izraela ze wszystkich narodów, gdzie zostali jeńcami, aby ich przywieźć do ziemi i na wzgórza izraelskie. Nazwie ich jednym ludem, rządzonym przez jednego króla ${ }^{36}$.

Jeśli więc Żydzi i chrześcijanie judaizujący chcieliby odnieść wszystko do królestwa tysiącletniego, z konieczności

Muszą uznać jako zbawionych tylko mieszkańców Ziemi Izraela. Ponadto to, że należy odbudować Jerozolimę, wznieść na nowo świątynię, odnowić wszystkie ceremonie nakazane przez prawo, zachowywać znowu szabat, poddać się bezprawnemu obrzezaniu ${ }^{37}$, uważać za największe szczęście jedzenie, picie, obfitość, bogactwo oraz wszelkie poważanie. A to mimo faktu, że Apostoł mówi: „Pokarm dla żołądka, a żołądek dla pokarmu. Bóg zaś unicestwi jedno i drugie" $(1$ Kor 6,13) 38 .

Autor Wulgaty nie stroni bynajmniej od ironii, podkreślając niektóre niepoważne aspekty i uwydatniając ich znaczenie. Ideologia niektórych chiliastów była nacechowana hedonizmem charakterystycznym dla Cerynta $^{39}$. Strydończyk z powodzeniem mógł wykazać absurdalność takich przekonań.

Najbardziej uderzające jest powtarzające się twierdzenie, że judaizujący oczekują nie tylko przyziemnych przyjemności i odbudowy ziem-

36 Hieronymus Stridonensis, Commentarii in Ezechielem XI 37.

37 Grzegorz z Nazjanzu wylicza również te elementy okresu millennium. Zob. Gregorius Nazianzenus, Epistulae 101, 63; 102, 16.

38 Hieronymus Stridonensis, Commentarii in Ezechielem XI 37.

39 Por. Eusebius Caesarensis, Historia ecclesiastica III 28; VII 25, 1-3; Newman, Jerome's Judaizers, s. 437. 
skiego Jeruzalem, ale także powszechnego przestrzegania żydowskiego prawa, szczególnie obrzędów ofiarniczych w świątyni, obrzezania i obchodzenia szabatu ${ }^{40}$.

Nadzieje chiliastów miały jednolity charakter. Przy odczytywaniu opisów dotyczących tej kwestii powtarza się motyw odnowy Jerozolimy ozdobionej klejnotami i antycypacja tysiącletniego królestwa na ziemi. Daje to wrażenie używanych wielokrotnie jednolitych formuł. W komentarzu do Iz 11,15-16 Strydończyk szczególnie często oskarżał judaizujących millenarystów o umiłowanie rozkoszy cielesnych.

Świadomy chrześcijański czytelnik powinien odnosić się do następującej zasady proroczych obietnic: bez względu na to, co twierdzą Żydzi i nasi judaizujący - a raczej nie my - [to, iż obietnice] wypełnią się cieleśnie, powinniśmy wykazać, że osiągnęliśmy to już duchowo, abyśmy nie byli zmuszani do judaizacji, zgodnie z tym, co mówi Apostoł o tego rodzaju baśniach i opowieściach bez końca (por. $1 \mathrm{Tm} 1,4)^{41}$.

W przypadku krytyki chiliazmu Hieronim okazuje się dłużnikiem Orygenesa. Podobnie jak Doktor Aleksandryjski zwalcza materialistyczne przekonania, broniąc interpretacji duchowej. Działo się tak szczególnie w przypadku tych tekstów biblijnych, którym millenaryści nadawali znaczenie dosłowne ${ }^{42}$. Wielu pisarzy z kręgu aleksandryjskiego należało do przeciwników millenaryzmu, stosując w swojej walce

40 Por. Hieronymus Stridonensis, Epistula 59, 3; Hieronymus Stridonensis, Commentarii in Esaiam 35, 3-10; 53, 2; 54, 11-14; 60, 1-3; 66, 20; prol. XVIII; Hieronymus Stridonensis, Commentarii in Ezechielem 36, 1-15; 37, 15-28; Hieronymus Stridonensis, Commentarius in Sophoniam 3, 19; 14, 10-11, 18-19; Hieronymus Stridonensis, Commentarius in Joelem 3, 7-8.

41 Hieronymus Stridonensis, Commentarii in Esaiam 11, 15-16. Por. Newman, Jerome's Judaizers, s. 437.

42 Orygenes określa chiliastów jako tych, „którzy wierzą wprawdzie w Chrystusa, ale pojmując Pisma Boże na sposób żydowski, nie wzięli z nich niczego, co było godne obietnic Bożych" (Origenes, De principiis II 11,2). 
interpretację alegoryczno-mistyczną obrazów apokaliptyczno-millenarystycznych ${ }^{43}$.

Hieronim nie tylko potwierdza fakt, że na łacińskim Zachodzie millenaryzm miał żywot o wiele dłuższy niż na terenach greckiego Wschodu ${ }^{44}$. Była to także doktryna żywa w kręgach judaizujących chrześcijan. Ich oddziaływanie nie ustało nawet wtedy, gdy doktryna millenarystyczna była już mocno osłabiona lub zupełnie zanikła dzięki rozszerzaniu się wpływów platonizmu (pogańskiego i schrystianizowanego).

\section{Problem podwójnej perspektywy odnowienia Jerozolimy}

Brzemienne w skutki było przekonanie Hieronima o do konieczności lektury duchowej porównań i obrazów Apokalipsy Janowej. Dotyczyło to wizerunku odnowionego miasta - niebiańskiego Jeruzalem. Dochodziło nawet do tego, że w kontekście apokaliptycznym już sama nazwa świętego miasta wydawała się kłopotliwa, choć sam Strydończyk przyznawał: „Nazywa się [również] Jerozolimą [miasto], które Żydzi i nasi judaizujący wyobrażają sobie zbudowane ze złota i drogich kamieni, przychodzące z niebios; według księgi Objawienia [świętego] Jana, której oni nie znają i nie rozumieją" ${ }^{45}$. W traktowaniu Apokalipsy Janowej" ${ }^{46}$ autor Wulgaty widzi dwie drogi:

Albo ową księgę należy tłumaczyć w sposób duchowy (ille liber aut spiritaliter intellegendus sit) - jak sądzimy - albo, jeśli chcemy pójść za interpretacją

43 Por. M. Simonetti, Lettera e/o allegoria. Un contributo alla storia dell'esegesi patristica, Studia Ephemeridis „Augustinianum” 23, Roma 1985, s. 295.

44 Wśród autorów łacińskich brakowało postaci tej miary jak Orygenes oraz tak kompleksowego i skutecznego systemu teologicznego jak aleksandryjski.

45 Hieronymus Stridonensis, Commentarii in Esaiam XIII 49, 14.

46 Chiliaści sprzeciwiali się interpretacji zdroworozsądkowej tej księgi biblijnej. Hieronim podkreśla niejednokrotnie, że Apokalipsę Janową „należy interpretować w sposób alegoryczny" (Hieronymus Stridonensis, Commentarius in Zachariam III 14, 10-11). 
dosłowną (si carnalem interpretationem sequimur), powinniśmy przyjąć do wiadomości wszystkie fantazje żydowskie: że Jerozolima zostanie odbudowana i znowu będą w niej sprawowane ofiary w świątyni, kult duchowy [natomiast] osłabnie, bo wezmą nad nim górę ryty materialne ${ }^{47}$.

Hieronim nie jest $\mathrm{w}$ tej opinii odosobniony ${ }^{48}$, gdyż również historyk Sokrates poświadcza, że Żydzi z diaspory mieli nadzieję powrotu do Ziemi Obiecanej i entuzjastycznie przyjmowali tych przywódców, którzy im to przyrzekali49. Być może Sokrates nawiązywał do ogólnej opinii chrześcijan o Żydach. Jest jednak pewne, że istniały pewne wątpliwości dotyczące przyszłości krain biblijnych i Jerozolimy. Fakt chrystianizacji Palestyny i świętego miasta być może z trudem docierał do świadomości nie tylko wiernych Staremu Prawu, lecz również do kręgów chrześcijan zafascynowanych judaizmem. Świadczy o tym list Hieronima do Dardanusa, na podstawie którego można przypuszczać, że chociaż uduchowienie wizerunku Jerozolimy znacznie się posunęło do przodu, nie było tak w przypadku całej Ziemi Świętej. W świetle Biblii chodzi o „kraj obietnicy" ${ }^{50}$, ale naród izraelski nigdy nie wszedł w całkowite jego posiadanie. Autor Wulgaty zauważa, że podobnie Jerozolima nie była nieprzerwanie miastem żydowskim ${ }^{51}$. Ruiny Jerozolimy pozostaną takimi aż do końca czasów ${ }^{52}$. Silnym argumentem w polemice z tymi, którzy byli przekonani o odbudowie zniszczonej Jerozolimy żydowskiej, było tradycyjne powołanie się na słowa Chrystusa ${ }^{53}$. Przepowiednie Zbawiciela, twierdzi Hieronim, odnoszą się do zdobycia Jerozolimy w 70 roku, ale także do

47 Hieronymus Stridonensis, Epistula 59, 3.

48 Por. Hieronymus Stridonensis, Commentarii in Esaiam XVIII 65, 21. Tekst mówi: „Quae omnia Iudaei accipiunt carnaliter, ut Hierusalem urbes que Iudaeae restituantur in pristinum statum”.

49 Por. Socrates Scholasticus, Historia ecclesiastica III 38.

50 Por. Hieronymus Stridonensis, Epistula 129, 1.

51 Por. Hieronymus Stridonensis, Epistula 129, 6.

52 Hieronymus Stridonensis, In Hieremiam prophetam IV 15.

53 Por. Hieronymus Stridonensis, In evangelium Matthaei IV (24,2). 
nadejścia antychrysta i końca świata ${ }^{54}$. Łaciński komentator nie cofa się przed ironią na temat powrotu do Jerozolimy wszystkich sprawiedliwych Żydów i judaizujących chrześcijan, którzy przy końcu czasów dokonają triumfalnego wyjścia „z niewoli”, aby wejść do krainy rozkoszy ${ }^{55}$.

Polemika z elementami egzegezy literackiej nie wiązała się wyłącznie $z$ antyjudaizmem naszego autora. Przyczyna takiej właśnie interpretacji proroctw tkwił $\mathrm{w}$ fakcie, iż millenaryzm na przełomie IV i V wieku przybrał materialistyczne i judaistyczne formy ${ }^{56}$. Ironizując na temat snów chiliastów o Jerozolimie zbudowanej ze złota i klejnotów, Strydończyk pisze:

[Prorok Zachariasz] rzecze: „Będą w niej mieszkali”, to znaczy w Jerozolimie, „a klątwa już jej nie dosięgnie”, to znaczy żadna obawa napadu ze strony nieprzyjaciół, ani strach, lecz „Jerozolima żyć będzie bezpiecznie” (Za 10,11) lub będzie zamieszkała, pozostając w pokoju na zawsze [...]. Uważamy, że niebiańskim Jeruzalem jest Kościół, który mimo, iż przebywa w ciele, nie postępuje według ciała, a [chwalebne miasto] należy do niebios ${ }^{57}$.

Duchowe tłumaczenie przepowiedni prorockich wskazuje, jak bardzo była paląca potrzeba przypomnienia ich „chrześcijańskiego” charakteru. To w przeciwieństwie do obrazów tradycji chiliastycznej i mówiących o wiecznym mieszkaniu w Judei i w Jerozolimie. Hieronim krytykuje ten punkt widzenia, mówiąc, że nie chodzi o „Judeę opusz-

54 Historycy chrześcijańscy z tamtej epoki piszący o tym rozdziale dziejów zwracają uwagę na niemożność odbudowy świątyni żydowskiej mimo stanowczych działań Juliana Apostaty. Podkreślali przy tym znaczenie teologiczne opisywanych wydarzeń. Por. Hieronymus Stridonensis, Commentarii in Danielem XI 34.

55 Por. Hieronymus Stridonensis, Commentarii in Esaiam XVII 60, 1-3; XVIII 66, 20; Hieronymus Stridonensis, Commentarii in Ezechielem XI 36, 16-38; Hieronymus Stridonensis, Commentarius in Zachariam III 14, 10-11.

56 Por. Hieronymus Stridonensis, Commentarii in Ezechielem 37,1-28.

57 Hieronymus Stridonensis, Commentarius in Zachariam III 14, 10-11. 
czoną w obecnym czasie i Jerozolimę obróconą w proch" ${ }^{58}$. Przypomina przy tej okazji opisy odbudowy świątyni in ultimo tempore ${ }^{59}$, odnowienia ofiar w przybytku i służby ,pogan”60, jak również wzmianki o Jerozolimie wzniesionej ze złota i drogich kamieni ${ }^{61}$. Egzegeta łaciński zawsze jednak zaznacza konieczność uduchowienia tych obrazów ${ }^{62}$ określanych jako „fantazje millenarystyczne" ${ }^{63}$. W opisie millenaryzmu Hieronim posługuje się uogólnieniami, chociaż ruch, który krytykuje, nie był bynajmniej monolityczny. Stara się przy tym podsumowywać główne jego zasady ${ }^{64}$. Bronią Hieronima była interpretacja proroctw odnoszących się do Jerozolimy w sposób historyczny i eklezjalny ${ }^{65}$. Tak formowała się krytyka millenaryzmu materialnego, nawet jeśli oczekiwania eschatologiczne były zakorzenione w zasadach wiary. Chrześcijanie bowiem „oczekują lepszej Ojczyzny, a jest nią niebiańskie Jeruzalem [cytat z Hbr 11,14-16]. Stąd wzięła się bajka o tysiącu lat, w którym to czasie przyrzeczone są małżeństwa, uczty i rozkosze ziemskiego życia"66.

58 Hieronymus Stridonensis, Commentarius in Ioelem III 20-21.

59 Por. Hieronymus Stridonensis, Commentarius in Amos IX 11-12.

60 Por. Hieronymus Stridonensis, Commentarii in Ezechielem 36, 1-15.

${ }^{61}$ Por. Hieronymus Stridonensis, Commentarii in Esaiam XXX 310. Por. również: Hieronymus Stridonensis, Commentarii in Esaiam XVII 60, 1, 13; XVIII 25, 1; Hieronymus Stridonensis, Commentarius in Ioelem III 7-8, 12-13.

62 Por. np. „Si spiritaliter, ut scripta est, disserimus” według Commentarii in Esaiam XVIII (praef.). Mówiąc o odbudowie Jerozolimy, Hieronim wyjaśnia, że chodzi o „miasto duchowe”, czyli Kościół odrzucony przez Żydów. Por. Hieronymus Stridonensis, Commentarii in Esaiam XIV 52, 9.

63 Por. M. Dulaey, Jérôme, Victorin de Petovio et le millenarisme, w: Jérôme entre l'Occident et l'Orient: XVIe centenaire du départ de saint Jérôme de Rome et de son installation à Bethléem. Actes du colloque de Chantilly, septembre 1986, ed. Y.-M. Duval, Paris 1988, s. 90.

64 Por. Hieronymus Stridonensis, Commentarii in Esaiam XVIII (prol); Hieronymus Stridonensis, Commentarii in Ezechielem XI 36, 1-15; Hieronymus Stridonensis, In Hieremiam prophetam IV 19, 10-11.

65 Por. Gozzo, De s. Hieronymi Commentario in Isaiae librum, s. 201-202.

66 Hieronymus Stridonensis, Commentarii in Esaiam XVI 58, 14. 
Walka z millenarystami posiada również i inny kontekst: interpretację biblijną należy włączyć w pobożność i perspektywę Kościoła ${ }^{67}$, co nie wykluczało wcale wątków eschatologicznych ${ }^{68}$. Wystarczyło zaakcentowanie, by obrazy millenarystycznej Jerozolimy odzyskały swoją „biblijność” i właściwe tłumaczenie. Hieronim jest głęboko przekonany, że służy temu wyjaśnienie duchowe. Tak na przykład w Jerozolimie przebywają

[ci, którzy] uwolnili się z więzów grzechu, odkupieni zostali krwią Zbawiciela, pokutowali i przyszli na Syjon. O nim [to] mówimy: „Przystąpiliście do góry Syjon, do miasta Boga żyjącego, Jeruzalem niebieskiego” (Hbr 12,22). Nie szukamy na sposób żydowski Syjonu ze złota i wysadzanej klejnotami Jerozolimy, która według proroctwa Daniela na wieki obróciła się w proch ${ }^{69}$.

Egzegeta łaciński dodaje, że aby chwalić Pana w Jeruzalem, należy podjąć trud nawrócenia ${ }^{70}$.

Księgę XV komentarza do Księgi Izajasza można uważać za próbę przywrócenia właściwego tłumaczenia obrazom wspaniałości odnowionego miasta Bożego ${ }^{71}$. Życie wieczne nie łączy się z przebywaniem w ziemskim mieście, gdzie można oddawać się radości i przyjemnościom. Obrazy apokaliptyczne nawiązują do „niebiańskiej Jerozolimy” nazwanej również „małżonką Baranka”72. „Chrystus zstąpił i wzniósł ponad ziemię niebiańską Jerozolimę, którą w Apokalipsie Jana nazywa

${ }^{67}$ Można to dostrzec nawet w lakonicznych interpretacjach, jak np. Hieronymus Stridonensis, Commentarii in Esaiam XVII 62, 4; Hieronymus Stridonensis, Commentarius in Amos II 4, 1-3.

68 W kontekście millenarystycznym Hieronim mówi o oddzieleniu plew od ziarna. Por. Hieronymus Stridonensis, Commentarii in Esaiam XVIII 65, 23.

69 Hieronymus Stridonensis, Commentarii in Esaiam X 35, 3.

70 Hieronymus Stridonensis, Tractatus in Ps. 136, 3-4.

71 Również i w tym przypadku nie brakuje ataków skierowanych w stronę Żydów i millenarystów.

72 Hieronymus Stridonensis, Commentarii in Esaiam XV 54, 11-14, 15. 
się Oblubienicą i Małżonką Baranka, a jej blask jest podobny do klejnotu"73. Owo „miasto duchowe”, twierdził Hieronim, było początkowo małe i bezbronne, wystawione na zniszczenia powodowane przez grzech i bałwochwalstwo. Przyjście Chrystusa zapoczątkowało okres budowy Kościoła na ziemi, który stawał się „miastem warownym” i ozdobionym drogimi kamieniami ${ }^{74}$, a jego mieszkańcy pochodzą „,z obu narodów”: Żydów i pogan ${ }^{75}$. Egzegeta łaciński odwoływał się do szerokiej gamy wersetów biblijnych, aby ustalić związek pomiędzy ziemską Jerozolimą, Kościołem i niebiańskim miastem jako rzeczywistością duchową ${ }^{76}$.

Twierdzenie Hieronima o tym, że przepowiednie odnoszące się do przyszłej chwały Jerozolimy interpretowano w sposób dosłowny, znajduje potwierdzenie w tekstach judaistycznych, które dotyczą ekspansji świętego miasta ${ }^{77}$. Strydończyk z tych właśnie względów sugeruje odbudowę Jerozolimy w sensie duchowym i przestrzega, że w pierwszym rzędzie „nie powinniśmy budować na obcych fundamentach”78. Nie brak elementów interpretacji duchowej ST, a przysłówek ,duchowo (spiritaliter)" posiada w tym kontekście podstawowe znaczenie. Dalmatyńczyk nie przepuszcza okazji, aby skierować ostrze polemiki przeciwko tym, którzy obietnice prorockie tłumaczą dosłownie (carnaliter), czyli, jak zwykle, Żydom i judaizującym chrześcijanom ${ }^{79}$. Nie tylko odwoływali się do oni nadziei odbudowy przybytku, ale także twierdzili, że owa budowla może ogarnąć w swoich murach Boga niewidzialnego, bezcielesne-

73 Por. Hieronymus Stridonensis, Commentarii in Esaiam XV 54, 11.

74 Por. Hieronymus Stridonensis, Commentarii in Esaiam XV 54, 11-14.

75 Por. Hieronymus Stridonensis, Commentarii in Esaiam XV 54, 15. Podobną myśl wyraża Leon Wielki. Por. Leo Magnus, Sermo XXVI 5.

76 Hieronim, mówiąc o deliramenta Żydów, ma na myśli ich rytualizm. Por. Hieronymus Stridonensis, Commentarii in Esaiam XV 54, 11-14.

77 Por. Hieronymus Stridonensis, Commentarii in Esaiam XVII 54, 1-3. Twierdzenia Hieronima potwierdza midrasz homiletyczny zwany Pesikta Rabbati, który bierze tekst Księgi Ezechiela za podstawę rozważań o odbudowie Jerozolimy. Por. także: S.H. Levey, The Targum of Ezekiel, Wilmington 1987, s. 100.

78 Hieronymus Stridonensis, Tractatus in Ps. 146, 2.

79 Por. także: Hieronymus Stridonensis, In Hieremiam prophetam VI 22. 
go i niepojętego ${ }^{80}$. Według świadectwa autora Wulgaty millenarystyczna wizja odbudowy Jerozolimy stała się niezwykle konkretna. Podobnie jak w kręgach apokaliptyków żydowskich ${ }^{81}$, również wśród epigonów millenaryzmu dyskutowano na temat wielkości odnowionej Jerozolimy. Polemista łaciński informował o tym, ale raczej zdawkowo i bez specjalnego roztrząsania tej kwestii ${ }^{82}$. Wyłącznie dzięki odnośnikom do Biblii owa wizja mogła oczyścić się z elementów niezdrowej fantazji ${ }^{83}$.

Kwestia proroctw zajmuje poczesne miejsce nie tylko ze względu na odradzający się chiliazm, ale również dlatego, że w kręgach egzegetów chrześcijańskich problematyka ta była często dyskutowana. Znajdywało to odbicie w komentarzach naszego autora, z reguły przedstawiającego rzadko porównanie pomiędzy stanem faktycznym stolicy Judei a wyobrażeniami millenarystów. O świetności ziemskiego miasta nasz autor mówi niemal wyłącznie w listach kierowanych do pragnących nawiedzić Ziemię Świętą ${ }^{84}$.

Hieronim nawiązuje do duchowej tradycji chrześcijaństwa, czerpiąc nie tylko z dziedzictwa myśli Orygenesa, ale także Euzebiusza z Cezarei. Autorzy ci nakreślili w wyczerpujący sposób chrześcijańską wizję świętego miasta. W komentarzach do proroctw elementy przez nich rozwijane przewijały się wyłącznie w odniesieniu do miasta niebiańskiego i Jerozolimy jako symbolu Kościoła. W czasach twórcy

80 Por. Hieronymus Stridonensis, Commentarii in Esaiam XVIII 66, 1.

81 Rabini z I wieku po Chrystusie uważali, że obszar odnowionej Jerozolimy rozciągnie się aż do Damaszku, aby móc przyjąć mieszkańców przybyłych z całego świata.

82 Odnowione przez Boga miasto miałoby zajmować obszar od Anatot po dolinę Cedronu. Teren, na którym znajdzie się odbudowana świątynia, także będzie pokaźny, a ,przybytek Pański [...] pozostanie na wieki”. Stanie się to na końcu czasów, „kiedy, według Apokalipsy Janowej, zstąpi Jeruzalem ze złota i drogich kamieni, aby stanąć na owym miejscu” (Hieronymus Stridonensis, In Hieremiam prophetam VI 29).

83 Relację Hieronima można zestawić z ujęciem typologicznym millenaryzmu dokonanym przez Metodego z Olimpu (druga połowa III wieku). Por. Daniélou, Théologie du Judéo-Christianisme, s. 358.

84 Por. Hieronymus Stridonensis, Epistulae 46, 58, 108, 129, 147; M.C. Paczkowski, Gerusalemme in Origene e San Girolamo, w: Gerusalemme. Realtà sogni speranze, ed. G. Bissoli, Jerusalem 1996, s. 115-118. 
Wulgaty chrześcijanie i Żydzi, udając się do tego samego miasta, mogli wzniecać spory o prawa własności, lecz nie ideologiczne. Rozumienie świętych tekstów było bowiem rozstrzygane na dwóch różnych płaszczyznach. Ojciec egzegezy łacińskiej był także bardzo daleki od zamykania horyzontu nadziei.

\section{Błądzący pasterze wspólnot i ich wizje Jerozolimy}

Hieronim deklarował, iż woli przemilczeć imiona tych, którzy hołdowali materialistycznej wizji millenium. Wydaje się jednak, że mnich z Betlejem nie mógł pominąć faktu, iż znani w kręgach kościelnych autorzy okazywali się millenarystami. Przedstawiając listę zwolenników chiliazmu z przeszłości, skupił się na postaci Wiktoryna z Petowium i wyjaśniał jego problematyczną wizję ${ }^{85}$. Jak wiadomo, autor Wulgaty poprawił i oczyścił z nadmiaru elementów millenaryzmu Komentarz do Apokalipsy Petowiańczyka ${ }^{86}$. Podobnego typu błędy wytykał Apolinaremu z Laodycei ${ }^{87}$. Hieronim wskazywał ponadto na chiliazm u Sulpicjusza Sewera, wymienionego obok innych autorów łacińskich ${ }^{88}$. U schyłku IV wieku postawa pasterzy sprzyjających chiliazmowi z pewnością nie zasługiwała na pochwałę.

Jak wiadomo, Wiktoryn z Petowium należał do zwolenników tradycyjnych schematów millenarystycznych. Strydończyk, chociaż ro-

85 Por. C. Curti, Girolamo e il millenarismo di Vittorino di Petovio, ASE 15/1 (1998) s. 191-203. Zob. również: M.C. Paczkowski, Alcuni aspetti teologici dell'Apocalisse in Vittorino di Petovio, BPTh 5 (2012) s. 175-206.

${ }^{86}$ Hieronim dokonuje korekt na zaproszenie Anatoliusza. Por. notę A. Hammana w: PLS 1, 103. Wiktoryn z Petowium był również pierwszym łacińskim autorem objaśniającym w sposób systematyczny księgi prorockie.

87 Por. Hieronymus Stridonensis, Commentarii in Esaiam XVIII (prol.); Hieronymus Stridonensis, Commentarii in Ezechielem XI 36.

88 Zob. Hieronymus Stridonensis, In Hieremiam prophetam XV 19, 10-11a. Por. Newman, Jerome's Judaizers, s. 441. 
dak Petowiańczyka, nie był nastawiony do niego zbyt entuzjastycznie. $\mathrm{W}$ jego ocenie był to mierny erudyta $\mathrm{z}$ wygórowanymi ambicjami ${ }^{89}$. Wiktoryn nie potrafił wyrazić w sposób adekwatny swoich przekonań ${ }^{90}$, a na dodatek znał grekę lepiej od łaciny ${ }^{91}$. Niejednokrotnie Hieronim wytyka Wiktorynowi jego sympatię do Orygenesa ${ }^{92}$, co potwierdzają w pełni tendencje alegoryczne pojawiające się w Komentarzu do Apokalipsy ${ }^{93}$.

Według Wiktoryna Jeruzalem niebiańskie charakteryzuje bogactwo wiary i łaski udzielonych za pośrednictwem Apostołów.

To, co mówi [autor Apokalipsy]: ujrzą „,różne drogie kamienie” (por. Ap 21,1820), odnosi się do ludzi, lecz oznacza także najcenniejszą różnorodność wiary poszczególnych osób. [Apostoł] wskazuje potem, że „bramy z pereł” (por. Ap 21,2) to Apostołowie. „Nie są [one] zamykane” (por. Ap 21,25), to znaczy: łaska została dana przez nich i nigdy jej nie zabraknie. Tutaj ujrzą [Boga] twarzą w twarz (por. 1Kor 13,12) ${ }^{94}$.

Elementem bardzo charakterystycznym jest zastosowanie przez Wiktoryna egzegezy alegorycznej wprzęgniętej w wyjaśnienie obrazów chiliastycznych. Mimo iż autor ten ogranicza się do kilku zaledwie wyrażeń biblijnych (Ap 20-21), potrafił ustrzec się przed koniecznością odrzucenia en bloc idei millenarystycznych, które były silnie zakorzenione w dosłownym tłumaczeniu Pisma Świętego przez niektórych pisarzy starożytnego Kościoła. Wiktoryn stara się zachować nie tylko tradycyjną duchową interpretację tekstów odnoszących się do obrazu Jerozolimy, lecz wykazuje sporą niezalleżność wobec metod, które wykorzystu-

\footnotetext{
89 Por. Hieronymus Stridonensis, Epistula 70, 5.

90 Por. Hieronymus Stridonensis, Epistula 58, 10.

91 Por. Hieronymus Stridonensis, De viris illustribus 74

92 Por. Hieronymus Stridonensis, Epistulae 61, 2; 84, 7.

93 Wiktoryn skomentował tylko 17 rozdziałów ostatniej księgi NT. Pominął Ap 9; $15 ; 16 ; 18 ; 22$.

94 Victorinus Poetoviensis, Commentarii in Apocalypsin 21, 6.
} 
$\mathrm{je}^{95}$. Cały kompleks porównań stosowanych w obrazie niebiańskiego Jeruzalem oznacza ,uduchowienie do maksimum” koncepcji miasta świętego. W ten sposób „Wiktoryn [...] kroczy po śladach wielkiego mistrza aleksandryjskiego (t.j. Orygenesa) ${ }^{\$ 96}$.

Kryzys millenaryzmu i jego schyłek były jednak procesami nieuniknionymi. Nie brakowało naśladowców Wiktoryna, którzy ukazując podstawy biblijne millenaryzmu, starali się go wskrzesicic ${ }^{97}$. Jednak interpretacja alternatywna wizji millenarystycznych była już zbyt ugruntowana, aby można było nawiązywać do nich jako do niezbitych argumentów świadczących o żywotności idei „tysiącletniego królestwa”. Chiliazm przechodził do lamusa koncepcji teologicznych.

Kwestie błędnej chrystologii u Apolinarego z Laodycei i millenaryzmu mogły być powiązane. W Palestynie apolinaryzm faktycznie zanikał po 400 roku, a więc w czasie intensyfikacji polemiki z przekonaniami millenarystów. Hieronim czuł się zobowiązany, by wskazać na błędy millenarystyczne u tego mistrza egzegezy i swego nauczyciela. Ze współczesnej perspektywy Laodycejczyk czasami jest oceniany jako „ostatni znaczący millenarysta na Wschodzie”, o którym zachowały się wzmiank ${ }^{98}$. Jego przekonania w tej kwestii mają jednak charakter martwego reliktu ${ }^{99} . Z$ drugiej strony trudno uwierzyć, że egzegeta i teolog takiego formatu jak biskup Laodycei, który chociaż lansował błędne, ale fascynujące teorie dotyczące osoby Chrystusa, zniżał się do głoszenia materialistyczny koncepcji eschatologicznych ${ }^{100}$. Hieronim podaje informację, że Apolinary napisał dwie księgi o zabarwieniu millenary-

95 Por. Curti, Il regno millenario, s. 432.

96 Curti, Il regno millenario, s. 431.

97 Wiele przykładów zaczerpniętych z Wiktoryna z Petowium podaje Curti w: Il regno millenario in Vittorino di Petovio, s. 427-428.

98 M. Simonetti, Il millenarismo cristiano dal I al V secolo, ASE 15/1 (1998) s. 16.

99 Zob. Simonetti, Millenarismo, s. 3282.

100 Por. E. Prinzivalli, Il millenarismo in Oriente da Metodio ad Apollinare, ASE 15/1 (1998) s. 151. 
stycznym. Nie robi jednak szczegółowych odnośników do wyrażonych tam sądów ${ }^{101}$.

W każdym razie Apolinary mówił wyraźnie o odnowie eschatologicznej świętego miasta, ale wycinkowość dokumentacji nie pozwala na bliższą analizę kontekstu i chronologii wydarzeń związanych z wypełnieniem się końca czasów. Jest jednak pewne, że biskup Laodycei zmienił sprawcę pierwszej odbudowy Jerozolimy w czasach eschatologicznych, gdyż nie jest to dzieło antychrysta, jak chcieli polemiści antyjudaistyczni, lecz Eliasza. Według zapowiedzi Dn 9,24-29 nastąpi to w „ostatnim tygodniu" 102 podzielonym na czas Eliasza i antychrysta. Świątynia Jerozolimska zostanie odbudowana nie przez antychrysta, lecz właśnie Eliasza. Po tej pierwszej odbudowie nastąpi powtórne odnowienie świętego miasta, już w chwili rozpoczęcia się królowania Chrystusa. Hieronim odwoływał się do tej idei, komentując zakończenie księgi Malachiasza ${ }^{103}$.

W głoszeniu słowa Bożego biskup Laodycei musiał jednak mieć świadomość, że wielu z jego słuchaczy, często ludzi prostych, ale szczerych w swej pobożności, nurtowały tego typu problemy. Być może Laodycejczyk, rozwijając popularne kwestie, liczył na przychylność jak największej grupy wiernych dla swoich teorii chrystologicznych. Być może znalazł ich w Palestynie. Znamienna w tym względzie jest relacja Grzegorza z Nyssy ${ }^{104}$.

Epifaniusz z Salaminy, podobnie jak św. Hieronim, należał do kręgu przyjaciół Apolinarego ${ }^{105}$. Biskup Salaminy nie był przekonany do końca

101 Por. Hieronymus Stridonensis, Commentarii in Ezechielem XI 36, 1-15; Hieronymus Stridonensis, De viris illustribus 18. Zob. B. Jeanjean, Saint Jérôme et l'hérésie, Paris 1999, s. 244.

102 Apolinary opierał się na wnioskach Juliusza Afrykańczyka. Por. M.C. Paczkowski, Girolamo e la polemica antiapollinarista, „Antonianum” 79/3 (2004) s. 499.

103 Zob. Hieronymus Stridonensis, Commentarius in Malachiam IV 5, 6.

104 Brat Bazylego Wielkiego wypowiada się negatywnie o odnowionych nadziejach millenarystycznych: „Czyż skłaniamy ludzi do pokładania nadziei w Jerozolimie ziemskiej, wyobrażając sobie jej odbudowę z najpiękniejszych drogich kamieni?” (Gregorius Nyssenus, Epistula 3, 24).

105 Trudno ich podejrzewać o stronniczość. Por. Epiphanius, Adversus haereses (Panarion) 77, 36-38; Hieronymus Stridonensis, Commentarii in Esaiam XVIII (prol.). 
o milenarystycznych tezach Apolinarego i mówił o „niepotrzebnym gadaniu" $(\pi \varepsilon \rho \iota \tau \tau \circ \lambda \circ \gamma \imath \tilde{\omega} \nu)^{106}$. Wzmiankuje jednak przekonania chiliastyczne Laodycejczyka ze względu na informatorów, którzy zapewniali, że taka była jego opinia ${ }^{107}$.

Mimo tak znaczącego spektrum przekonań o charakterze chiliastycznym, u Apolinarego ma się do czynienia już raczej z doktryną połowiczną i o charakterze pochodnym. To raczej niektórzy z jego uczniów lansowali millenaryzm. Laodycejczyk odwoływał się przede wszystkim do egzegezy literackiej, którą określano jako „żydowską"108. Jak się wydaje, napotkał on również problem ewentualnego odnowienia niektórych praktyk rytualnych Starego Testamentu w czasach eschatologicznych. Biskup Laodycei nie krył jednak swoich ocen krytycznych wobec braku wiary Hebrajczyków. Sięganie z kolei po koncepcje judaizmu tworzy wrażenie schizofrenii w egzegezie Laodycejczyka. To z pewnością poważny mankament jego refleksji.

Hieronim znał z autopsji treść głoszonych kazań i nauk biskupa Laodycei. W okresie wybuchu sporów wokół doktryny apolinarystycznej egzegeta łaciński był owładnięty myślą o konieczności zwalczania millenaryzmu. Był to czas, gdy komentował księgi prorockie, więc sięgając pamięcią do nauk z przeszłości, szukał materiału i dostrzegał słabe strony egzegezy, w tym interpretacji ściśle literackiej Apolinarego. Była ona widoczna szczególnie w odniesieniu do eschatologicznych obrazów zapowiedzi prorockich. Hieronim pozostał jednak w sferze bardzo ogólnej, mimo że przy opisie millenaryzmu Apolinarego nie szczędził cierpkich uwag i nie unikał osobistych ataków.

106 Epiphanius, Adversus haereses (Panarion) III 77, 36. Biskup Salaminy wskazuje następnie na konieczność interpretacji duchowej Apokalipsy Janowej.

107 Według tego niewątpliwego znawcy wszelkich błędów doktrynalnych biskup Laodycei głosił, że „w okresie pierwszego zmartwychwstania, [wierni] będą przeżywać okres tysiąca lat w tych samych warunkach, co w obecnym czasie, to znaczy zachowując Prawo i inne nakazy, wszystko czego potrzebujemy na tym świecie, zawierając małżeństwa, obrzezanie i wszystko inne". Epiphanius, Adversus haereses (Panarion) III 77, 36.

108 Por. Hieronymus Stridonensis, Commentarii in Danielem III 9, 24. 
Laodycejczyk być może starał się o stworzenie syntezy pomiędzy koncepcjami judaistycznymi a chrześcijańskimi. Możliwe, że biskup azjatycki nawiązał do dyskusji odnoszących się do odbudowy Świątyni Jerozolimskiej przez Juliana Apostatę ${ }^{109}$, co wzbudziło nadzieję odnowy narodu wybranego i wypełnienie się obietnic mesjańskich dla Żydów ${ }^{110}$. Wydarzenia związane z panowaniem Apostaty być może sprawiły, że odrodziły się idee millenarystyczne, które znalazły posłuch w Palestynie ${ }^{111}$, stąd Hieronim czuł się wręcz zobowiązany, by dać skuteczny odpór judaizującym, w tym apolinarystom ${ }^{112}$.

Hieronim zwraca szczególną uwagę na judaizujących apolinarystów w komentarzach do Księgi Izajasza i Księgi Ezechiela. Tam w szczególny sposób musiał skonfrontować się z założeniami dosłownej lektury obietnic eschatologicznych ${ }^{113}$. W komentarzu do Księgi Daniela problem jest zasygnalizowany w sposób bardzo ogólny:

Apolinary z Laodycei unika wszelkich problemów związanych z przeszłością, aby skierować spojrzenie ku przyszłości, lecz to niebezpieczna gra i konstruowanie twierdzeń na niestałych fundamentach. Gdy przypadkiem ci, którzy żyjąc po nas, nie dostrzegą wypełniania się obiecanych zapowie-

109 Na ten temat istnieje szereg publikacji. Ograniczamy się tylko do następujących: L. Lugaresi, „,Non su questo monte, né in Gerusalemme”: modelli di localizzazione del sacro nel IV secolo. Il tentativo di ricostruzione del Tempio nel 363 D.C., „Cassiodorus” 2 (1996) s. 245-265; M.C. Paczkowski, Rzeczywistość i symbolika świątyni jerozolimskiej w pismach wczesnochrześcijańskich (II-III w.), CT 79/2 (2009) s. 99-100.

110 Według Bazylego Wielkiego to przekonanie zakładało, że chrześcijanie staną się Żydami. Por. Basilius Caesariensis, Epistula 263, 4; A. Capone, Apollinarismo e geografia ecclesiastica. Luoghi e forme della polemica, „Auctores Nostri” 9 (2011) s. 466.

111 Por. Gregorius Nyssenus, Epistula 3, 24-26.

112 Bazyli Wielki przypisywał te przekonania już starczemu wiekowi biskupa Laodycei i jego fantazjom czy wręcz urojeniom. Zob. Basilius Caesariensis, Epistula 265, 2. Zob. również Gregorius Nazianzenus, Epistulae 101, 63; 102, 14.

113 Przykłady w: Hieronymus Stridonensis, Commentarii in Esaiam IV 11, 6-9, 15-16; V 23, 18; Hieronymus Stridonensis, Commentarii in Ezechielem XI 23, 1-23. Komentarz Apolinarego do Księgi Izajasza był znany Hieronimowi i został przez niego wykorzystany. Por. M. Simonetti, Sulle fonti del Commento a Isaia di Girolamo, „Augustinianum” 24 (1984) s. 451-469. 
dzi, będą zmuszeni poszukać innego thumaczenia i oskarżą mistrza, że mówił głupstwa ${ }^{114}$.

Oto mała próbka przekonań Apolinarego, który przechodzi od ogółu do szczegółu:

Rzeczy zniszczone na ziemi nie przestają istnieć u Boga - pisze Laodycejczyk - lecz w Nim nadal istnieją rzeczy, których już nie ma [...]. Tak samo Jerozolima z powodu świętych, dla których to miasto jest godne czci, jako matka świętych. [To miasto] powstanie, gdyż jest przedmurzem niebiańskiego Jeruzalem ${ }^{115}$.

Mnich z Betlejem uważał, że według Apolinarego nie jest możliwe rozdzielanie epok, które po sobie następują. Wynika to z proroctwa Dn 9,24-29, często zresztą wyjaśnianego przez autorów chrześcijańskich. Strydończyk wskazuje, że interpretacja dosłowna prowadzi do ściśle określonych wniosków, czemu to poświęca nieco uwagi. Odnowa millenarystyczna oznacza przywrócenie do stanu z okresu monarchii króla Dawida $^{116}$. Perspektywa żydowska zmienia duchowe aspekty eschatologii w obietnice natury materialnej i politycznej. Iz 65 był tekstem bardzo użytecznym w polemice $\mathrm{z}$ chiliastami ${ }^{117}$.

Za kulisami chiliazmu, określanego jako ,judaizowanie”, kryje się być może chęć nakreślenia takiego obrazu szczęśliwości, aby wyjść naprzeciw wszystkim aspiracjom zarówno kręgów chrześcijańskich, jak i żydowskich. Stąd twierdzenie o odnowie kultu żydowskiego

114 Hieronymus Stridonensis, Commentarii in Danielem III 9, 24.

115 Por. A. Mai - G. Cozza-Luzi, Nova Patrum Bibliotheca, 7: pars 2: Origenis, Didymi, Hippolyti, Apollinaris, Polychronii scholia in Proverbia, Esaiam, et Ezechielem cum Didymi uberioribus in Psalmos, Roma 1854, s. 129.

116 Por. Hieronymus Stridonensis, Commentarii in Esaiam 65, 21.

117 Por. teksty wskazane w: P. Jay, L'éxègese de saint Jérome d'apres son „, Commentaire sur Isaie”, Paris 1985, s. 322-323. 
w Jerozolimie ${ }^{118}$. Biskup Laodycei chciał ponadto pozyskać sympatyzujących z judaizmem, u których próba odbudowy świątyni w Jerozolimie przez Juliana Apostatę obudziła nadzieje rychłego nastania okresu pomyślności i odnowy Izraela.

Od IV wieku począwszy, do przyczyn, które zdecydowały o upadku millenaryzmu, dochodzi zmiana położenia chrześcijaństwa i wartościowania rzeczywistości doczesnej. Ta ostatnia wydawała się tym bardziej do zaakceptowania, iż religia chrześcijańska mogła cieszyć się wolnością ${ }^{119}$. Wyznawcy Chrystusa od tej pory nie byli już więcej „przeciwko światu”, lecz „w świecie”. Kierunek historii okresu stał się nadzwyczaj czytelny i wyznaczały go nieustanne postępy w rozprzestrzenianiu się Ewangelii na świecie. W ten sposób także bladły sny o odbudowanej i upiększonej Jerozolimie, a niebiańskie miasto nie było jedyną możliwością realizacji królestwa Bożego i zwycięstwa Kościoła ${ }^{120}$. Nie chodziło bynajmniej o „koniec historii”, ale o początek dziejów związanych jak najściślej z duchowością i naukami ewangelicznymi. W mniejszym lub większym stopniu jest to wizja wszystkich pisarzy chrześcijańskich na przełomie IV i V wieku.

Szereg okoliczności skłoniło św. Hieronima do zajęcia krytycznej postawy wobec millenarystów. Byli oni przedstawicielami tendencji judaistycznych w egzegezie, teologii i praktyce życia chrześcijańskiego. Przebywając w Palestynie, Strydończyk zetknął się z konkretnymi problemami tamtejszej wspólnoty chrześcijańskiej. Kwestia chiliazmu

118 Epifaniusz z Salaminy nie jest zbytnio przekonany o obecności tych elementów w doktrynie eschatologicznej Apolinarego. Por. Epiphanius, Adversus haereses (Panarion) II 77, 36.

119 Por. przede wszystkim: R. Farina, L'Impero e l'imperatore cristiano in Eusebio di Cesarea, Zurich 1966.

120 Św. Hieronim potwierdza opinię o wspaniałości budowli chrześcijańskich. Uważa nowe kościoły wzniesione w Jerozolimie za zwycięskie sztandary nowej wiary. Przewyższają one rzeczywistość ST. Zob. Hieronymus Stridonensis, In Hieremiam prophetam IV, 15 (19); Hieronymus Stridonensis, Commentarii in Esaiam XIII 49, 14. 
nie była być może wiodąca w polemikach prowadzonych przez mnicha z Betlejem, ale ujawniła swoje niepoślednie znaczenie w interpretacji ksiąg prorockich i Apokalipsy Janowej. Przedstawiciele millenaryzmu, tacy jak Wiktoryn z Petowium i Apolinary z Laodycei, byli również przedmiotem krytyki ze strony autora Wulgaty. Jednak także i tu polemika Hieronima nie jest tak rozległa i zaangażowana, jak w innych przypadkach. Millenaryzm najwyraźniej był już doktryną przebrzmiałą, choć jeszcze wyznawaną w niektórych kręgach. Mógł się także odradzać wskutek działań promujących odbudowę Świątyni Jerozolimskiej, jak w przypadku Juliana Apostaty. Echa tego wydarzenia pojawiały się często w pismach autorów ówczesnej epoki. Refleksja św. Hieronima jest tym cenniejsza, że łączy on pierwotne wątki teologii coraz bardziej marginalizowanych chrześcijan ex circumcisione ze zdobyczami egzegezy osadzonej w tradycji Kościoła i w dociekaniach filologiczno-naukowych.

\section{The Critique of the Millenarian Image of Jerusalem in St. Jerome of Stridon}

(summary)

The purpose of this study is to examine St. Jerome's critical disposition towards the millenarian image of Jerusalem. In the set of controversies undertaken by the Stridonian, the topic is worthy of interest. He is opposed to Chiliastic convictions in the Judaizing current in exegesis and the controversy with the authors who radicalized these ideas drawn from the scriptural images. However, it can be seen that the author of the Vulgate reached for the legacy of the exegetical tradition of the literal sense. In Jerome, we find a double perspective of the renewal of Jerusalem, as an earthly and glorious city in the heavens. Some shepherds of the communities also wandered in this matter, among which the Dalmatian indicates Victorinus of Poetovium and Apollinaris of Laodicea. The pages on the millenarian topic in Jerome's writings testify that he was implicated in this controversy for various reasons.

Keywords: Jerome of Stridon; Jerusalem; Millenarianism; Eschatology; Judaizers; Patristic literature; Victorinus of Poetovium; Apollinaris of Laodicea 


\title{
Krytyka millenarystycznego obrazu Jerozolimy u św. Hieronima ze Strydonu
}

\author{
(streszczenie)
}

Celem opracowania jest ukazanie krytycznego nastawienia św. Hieronima ze Strydonu do millenarystycznego obrazu Jerozolimy. W całościowym kompleksie kontrowersji podejmowanych przez Strydończyka millenaryzm to temat godny dokładniejszej analizy. Sprzeciwiał się on chiliastycznym nurtom wśród judaizujących egzegetów i podejmował dyskusje z autorami, którzy wypaczali wymowę obrazów biblijnych. Można jednak dostrzec, że sam autor Wulgaty sięgał po dziedzictwo egzegetycznej tradycji dosłownego znaczenia. U Hieronima daje się zauważyć podwójną perspektywę odnowienia Jerozolimy: jako miasta ziemskiego, lecz również chwalebnego na niebie. Odnośnie do obrazów millenarystycznych błędne postawy reprezentowali także niektórzy pasterze wspólnot, wśród których Dalmatyńczyk wskazuje Wiktoryna z Petowium i Apolinarego z Laodycei. Stronice poświęcone kwestiom millenium w pismach Hieronima świadczą o tym, że był on zaangażowany w tę kontrowersję z różnych powodów.

Słowa kluczowe: Hieronim ze Strydonu; Jerozolima; millenaryzm; eschatologia; judaizujący; literatura patrystyczna; Wiktoryn z Petowium; Apolinary z Laodycei

\section{Bibliografia}

\section{Źródła}

Basilius Caesariensis, Epistulae, t. 1-3, ed. Y. Courtonne, Paris 1957-1966, tł. W. Krzyżaniak, Św. Bazyli Wielki, Listy, Warszawa 1972.

Epiphanius, Panarion, t. 3, ed. J. Dummer, GCS 64, Berlin - Leipzig 1985.

Eusebius Caesariensis, Historia ecclesiastica, ed. E. Schwartz, GCS 9/2, Leipzig 1908, tł. A. Lisiecki, Euzebiusz z Cezarei, Historia Kościelna, POK 3, Poznań 1924.

Gregorius Nazianzenus, Epistulae, PG 37, 21-388, tł. J. Stahr, Św. Grzegorz z Nazjanzu, Listy, POK 15, Poznań 1933.

Gregorius Nyssenus, Epistulae, PG 46, 999-1108.

Hieronymus Stridonensis, Commentarii in evangelium Matthaei, ed. D. Hurst - M. Adriaen, CCL 77, Turnhout 1969, tł. J. Korczak, Hieronim ze Strydonu, Komentarz do Ewangelii wedtug św. Mateusza, ŹMT 46, Kraków 2008.

Hieronymus Stridonensis, In Hieremiam prophetam, ed. S. Reiter, CCL 74, Turnhout 1960.

Hieronymus Stridonensis, Commentarii in Danielem, ed. F. Glorie, CCL 75, Turnhout 1964. 
Hieronymus Stridonensis, Commentarii in Esaiam, ed. M. Adriaen, CCL 73-73A, Turnhout 1963-1970.

Hieronymus Stridonensis, Commentarii in Ezechielem, ed. F. Glorie, CCL 75, Turnhout 1964.

Hieronymus Stridonensis, Commentarii in prophetas minores: In Osee, In Ioelem, In Amos, In Michaeam, In Sophoniam, In Zachariam, In Malachiam, ed. M. Adriaen - D. Vallarsi, CCL 76, 1-158; 159-209; 211-348; 421-524; CCL 76 A, 655-711; 747-900, 901942, Turnhout 1970.

Hieronymus Stridonensis, Commentarii in Epistulam Pauli Apostoli ad Galatas, ed. G. Raspanti, CCL 77 A, Turnhout 2006.

Hieronymus Stridonensis, De viris inlustribus, ed. E.C. Richardson, TU 14, Leipzig Berlin 1896, tł. W Szołdrski, Św. Hieronim, O znakomitych mężach, PSP 6, Warszawa 1970.

Hieronymus Stridonensis, Epistulae, ed. I. Hilberg, CSEL 54, Wien - Leipzig 1910, tł. J. Czuj - M. Ożóg, Hieronim, Listy, t. 1-5, ŹMT 54-55; 61; 63; 68, Kraków 2010-2013.

Hieronymus Stridonensis, Tractatus sive Homiliae in Psalmos, ed. G. Morin, CCL 78, Turnhout 1958.

Irenaeus Lugdunensis, Adversus haereses, t. 2, ed. A. Rousseau - L. Doutreleau, SCh 293-294, Paris 1982.

Leo Magnus, Sermones, t. 1, ed. J. Leclercq - R. Dolle, SCh 26, Paris 1947, tł. K. Tomczak, Św. Leon Wielki, Mowy, POK 24, Poznań 1958.

Origenes, Commentarii in Iohannem, t. 1, éd. C. Blanc, SCh 120, Paris 1966, tł. S. Kalinkowski, Orygenes, Komentarz do Ewangelii św. Jana, ŹMT 27, Kraków 2003.

Origenes, De principiis, t. 2, ed. H. Crouzel - M. Simonetti, SCh 252, Paris 1978, tł. S. Kalinkowski, Orygenes, O zasadach, PSP 23, Warszawa 1979.

Origenes, Fragmenta e catenis in Psalmos, ed. J.B. Pitra, Analecta sacra 3, Venetiis 1883.

Origenes, Homiliae in Isaiam, ed. W.A. Baehrens, GCS 33, Leipzig 1925, tł. S. Kalinkowski, Orygenes, Homilie o Księgach Izajasza i Ezechiela, ŹMT 16, Kraków 2000.

Origenes, Homiliae in Jeremiam, t. I-XI, ed. P. Nautin - P. Husson, SCh 232, Paris 1976, tł. S. Kalinkowski, Orygenes, Homilie o Księdze Jeremiasza, PSP 30, Warszawa 1986.

Socrates Scholasticus, Historia ecclesiastica, PG 67, 33-841, tł. S. Kazikowski, Sokrates Scholastyk, Historia Kościoła, Warszawa 1972. 
Victorinus Poetoviensis, Commentarii in Apocalypsin, ed. M. Dulaey, SCh 423, Paris 1997 .

\section{Opracowania}

Braverman J., Jerome's commentary on Daniel. A study of comparative Jewish and Christian interpretations of the Hebrew Bible, The Catholic Biblical Quarterly. Monograph Series 7, Washington 1978.

Capone A., Apollinarismo e geografia ecclesiastica. Luoghi e forme della polemica, „Auctores Nostri” 9 (2011) s. 457-473.

Curti C., Girolamo e il millenarismo di Vittorino di Petovio, ASE 15/1 (1998) s. 191-203.

Daniélou J., Théologie du Judéo-Christianisme, Histoire des doctrines chrétiennes avant Nicée 1, Paris - New York - Rome 1958.

Dulaey M., Jérôme, Victorin de Petovio et le millenarisme, w: Y.-M. Duval, Jérôme entre l'Occident et l'Orient: XVIe centenaire du départ de saint Jérôme de Rome et de son installation à Bethléem. Actes du colloque de Chantilly, septembre 1986, Paris 1988, s. 83-98.

Farina R., L'Impero e l'imperatore cristiano in Eusebio di Cesarea, Zurich 1966.

Gozzo S., De s. Hieronymi Commentario in Isaiae librum, „Antonianum” 35 (1960) s. 49-80, 171-214.

Guinot J.-N., Théodoret et le millénarisme d'Apollinaire, ASE 15/1 (1998) s. 173-178.

Jay P., L'éxègese de saint Jérome d'apres son „C Commentaire sur Isaie”, Paris 1985.

Klijn A.F.J. - Reinink G.J., Patristic Evidence for Jewish-Christian Sects, Leiden 1973.

Levey S.H., The Targum of Ezekiel, Wilmington 1987.

Lieu J., History and Theology in Christian Views of Judaism, w: The Jews Among Pagans and Christians, ed. J. Lieu - J. North - T. Rajak, London 1994, s. 79-96.

Lugaresi L., „, Non su questo monte, né in Gerusalemme”: modelli di localizzazione del sacro nel IV secolo. Il tentativo di ricostruzione del Tempio nel 363 D.C., „Cassiodorus" 2 (1996) s. 245-265.

Mai A. - Cozza-Luzi G., Nova Patrum Bibliotheca, 7: pars 2: Origenis, Didymi, Hippolyti, Apollinaris, Polychronii scholia in Proverbia, Esaiam, et Ezechielem cum Didymi uberioribus in Psalmos, Roma 1854. 
Newman H.I., Jerome's Judaizers, JECS 9/4 (2001) s. 421-452.

O’Connell J.P., The eschatalogy of Saint Jerome, Mundelein 1948.

Paciorek P., Czas kresu czasów w literaturze apokaliptycznej, VoxP 62 (2014) s. 383-425.

Paczkowski M.C., Alcuni aspetti teologici dell'Apocalisse in Vittorino di Petovio, BPTh 5 (2012) s. 175-206.

Paczkowski M.C., Gerusalemme in Origene e San Girolamo, w: Gerusalemme. Realtà sogni speranze, ed. G. Bissoli, Jerusalem 1996, s. 106-123.

Paczkowski M.C., Girolamo e la polemica antiapollinarista, „Antonianum” 79/3 (2004) s. 473-504.

Paczkowski M.C., Rzeczywistość i symbolika świątyni jerozolimskiej w pismach wczesnochrześcijańskich (II-III w.), CT 79/2 (2009) s. 77-100.

Prinzivalli E., Il millenarismo in Oriente da Metodio ad Apollinare, ASE 15/1 (1998) s. $125-151$.

Simonetti M., Il millenarismo cristiano dal I al V secolo, ASE 15/1 (1998) s. 7-20.

Simonetti M., Lettera elo allegoria. Un contributo alla storia dell'esegesi patristica, Studia Ephemeridis „Augustinianum”23, Roma 1985.

Simonetti M., Millenarismo, w: NDPAC, t. 2, ed. A. Di Berardino, Genova 2008, s. $3280-3282$.

Simonetti M., Sulle fonti del Commento a Isaia di Girolamo, „Augustinianum” 24 (1984) s. 451-469.

Stroumsa G.G., Savoir et salut, Paris 1992.

Taylor J.E., Christians and the Holy Places. The Myth of Jewish Christian Origins, Oxford 1993.

Wilken R.L., Early Christian Chiliasm, Jewish Messianism, and the Idea of the Holy Land, HTR 79/1 (1986) s. 298-307. 